\title{
The Use of e-Learning in Vocational Education and Training (VET): Systematization of Existing Theoretical Approaches
}

\author{
Vera Belaya ${ }^{1}$ \\ ${ }^{1}$ Leibniz Institute of Agricultural Development in Transition Economies (IAMO), Germany \\ Correspondence: Vera Belaya, Theodor-Lieser-Str. 2, 06120 Halle (Saale), Germany.
}

Received: May 12, 2018

Accepted: July 3, $2018 \quad$ Online Published: July 20, 2018

doi:10.5539/jel.v7n5p92

URL: https://doi.org/10.5539/jel.v7n5p92

\begin{abstract}
Vocational education and training (VET) has been facing a lot of challenges lately in the context of geostrategic forces that are shaping our world. Recent technological changes, combined with shifts in global economic power, accelerating urbanization, and demographic changes have put pressure on the VET to become more responsive to the needs of the labour market and society. E-learning has been seen as an effective way of improving the quality of teaching and learning in VET schools due to its various forms. Nevertheless, there has been some disagreement in the litearture on the advantages and disadvantages of the use of of e-learning in VET. Besides, some studies recently reported a decline in enthusiasm about the effects of e-learning in companies. In order to closely examine the effects of e-learning in VET, we conduct a literature review. We then carry out a discussion of the pros and cons with the aim of developing suggestions for the better use of e-learning in VET. The results of the litearture review show that learners and providers of e-learning benefit from it in different ways. In order to minimise the risks involved in using e-learning, a mixture of online and face-to-face events could be used, and adjusted pedagogical concepts should be designed and developed explicitly for e-learning.
\end{abstract}

Keywords: vocational education and training (VET), e-learning

\section{Introduction}

\subsection{Statement of the Problem}

Many companies are facing increasing skill demands, and cost and innovation pressures caused by ongoing globalisation and the internationalisation of markets. The internationalisation of many areas of responsibility requires additional qualifications and new skills and has a lasting influence on the learning processes and workflows within companies. Moreover, digitisation and electronic networking are becoming increasingly prevalent in our everyday lives. The proliferation of computers, smartphones, and other digital media means that we now have access to an ever wider range of media. As a result, training needs have grown in many companies. In order to meet those changing needs of the business companies VET schools are expected to equip students with skills demanded from the companies which correspond to the latest technologies. However, due to the scarcity of resources as well as cost pressures, this increased need for training can no longer be covered by classroom teaching alone. The appearance of new digital media has supported the spread of e-learning (Gros \& García-Peñalvo, 2016). The use of electronic media is, therefore, taking on a more important role. In this context, new forms of teaching and learning under the umbrella term "e-learning" are becoming increasingly important in VET.

In recent decades, e-learning has become an important learning and teaching mode at all levels of education higher education, vocational training and also in primary and secondary schools (Gros \& García-Peñalvo, 2016). However, e-learning is not a new method of knowledge transfer, but rather the conveyance of information using new media (Eickhoff, 2008). Theoretical discussions around e-learning focus primarily on how to use it as a means of improving the efficiency of VET (Dittler, 2003, Riekhof \& Schüle, 2002, Scheffer \& Hesse, 2002). Many companies and VET schools place high hopes in e-learning. But what are the arguments in favour of e-learning? Above all, the benefits of e-learning are that it eliminates the need to travel to the educational facilities, and allows the time, place, and pace of learning to be determined by the learner (Huchthausen \& Droste, 2014). It is, therefore, clear that the topic of e-learning is of current and future relevance. In addition to the temporal and spatial flexibility offered to teachers and learners, the use of electronic media in the learning process promises to increase the motivation to learn, improve learning performance, and reduce training costs 
(Howe \& Knutzen, 2012). However, although many sources of literature indicate that e-learning can improve teaching and learning in VET, its integration into existing VET programmes is seen as a complex process which involves a number of different obstacles (Balanskat et al., 2006). Those obtacles include teacher behaviour and attitude towards e-learning, as well as the need to modern technological infrastructure in VET institutions (Brolpito et al., 2016). Further barriers to the acceptance of e-learning in VET include various competence levels of teachers and trainers, as well as different educational traditions and cultural predispositions in VET institutions (Heuel \& Feldmann, 2014). Besides, there is some evidence that the enthusiasm surrounding e-learning has gradually declined. Some companies have already had negative experiences with e-learning and it sometimes fails to live up to the high expectations placed on it (Reglin \& Severing, 2003).

It is, therefore, necessary to take a look at the causes behind these trends in order to possibly understand why e-learning has only achieved moderate success in some cases. In addition, some inconsistencies in the literature, e.g. no common definition of the term "e-learning", different spellings (eLearning, E-Learning, e-Learning), and different approaches to classifying the types of use and forms of e-learning, point to the need for critical analysis and systematisation of the existing views and concepts that deal with e-learning. Furthermore, it is important to examine more closely the pros and cons of e-learning versus traditional learning formats in order to find the most effective and successful use of e-learning for VET.

\subsection{Objectives and Approach}

The aim of this paper is to provide information on the current state of research on e-learning and to develop recommendations for the better use of e-learning in VET. In order to achieve this goal, four key areas around the subject "e-learning" with regard to VET are treated by means of a literature review: definition, forms, advantages and disadvantages of e-learning. In the second chapter, the theoretical foundations of e-learning are set. First, the term "e-learning" is defined. There are many different definitions and similar terms in the literature that address learning through electronic media. Therefore, it is first necessary to define the term and find a suitable definition in the context of VET. Following this, the different forms of e-learning are presented. As there are many different forms, it is necessary to classify these according to certain criteria. Identifying existing classification criteria and forms of e-learning could prove helpful for further study of the subject matter. The third chapter is dedicated to the positive and negative aspects of e-learning in comparison to classic learning formats used in VET. For this purpose, the advantages and disadvantages of e-learning are presented based on existing approaches, concepts and opinions in the scientific literature, and a comparison is made. The most important findings are presented in a table in order to provide a better overview. A discussion of the pros and cons is carried out with the aim of developing suggestions for the better use of e-learning in VET. This work does not aim for full coverage of the topic, but only looks at some 40 selected literature sources that represent larger thematic groups for the period 2001-2018.

\section{E-learning in VET}

\subsection{Definition of e-learning}

The concept of e-learning has been in existence since the second half of the 1990s (Howe \& Knutzen, 2012). It was first used at a seminar and from there spread very quickly. However, the use of the term has not always been consistent (Strittmatter \& Niegemann, 2000). In dealing with the subject of digital media, a variety of terminology can be identified, which is used more or less synonymously with the term "e-learning". Examples include: computer- or web-based training or learning, multimedia learning, computer-aided learning, mobile learning, online learning, distance learning, electronic learning, tele-learning, tele-teaching, and distance education. This flood of concepts came about as a result of the rapid development of information and communication technologies that created new corresponding word creations. Even the spelling varies: eLearning, E-Learning, e-Learning. Nevertheless, the word combination of the two components "e" and "learning" is not self-explanatory (Schnekenburger, 2009). The term e-learning is multifaceted, making the search for a common definition more difficult. According to Lehmann and Bloh (2002), e-learning is a collective term for all kinds of virtualised teaching and educational offers. Schnekenburger (2009) defines e-learning as learning with electronic media. The difference between these two definitions lies essentially in the words "virtualised" and "electronic". Other authors use the term e-learning to mean the use of the Internet when learning. For example, Döring (2005) points out that the term e-learning is not a unified form of learning or teaching, but represents a collective term for various teaching-learning scenarios using online media. Reinmann-Rothmeier (2003) argues that e-learning is used as a collective term for all types of media-based learning, including both intranet and internet based. These definitions all have one thing in common: the authors agree that e-learning is not an independent learning form, strategy or method. Rather, e-learning is related to the support of learning processes using electronic, digital or 
Internet-based media or telecommunications networks - the learning process remains the same. One current definition is: "E-learning is the electronic support of learning, whereby, in terms of implementation, particular focus lies on the specific didactic preparation and production of learning content for delivery through electronic media, as well as the underlying (up-to-date) software and technical platforms." (Sitzmann, 2015). However, examination of the terminology in the literature leads to another important insight: despite the similarities mentioned, most definitions of e-learning can be divided into two groups. The first group of definitions covers e-learning as a generic term for computer-aided learning in the broad sense. All possible forms of teaching and learning are implied: computer-aided, multimedia, tele-medial, net-based (Riekhof and Schüle, 2002). According to the literal meaning of the term "electronic media", not only the computer but also the television, the radio and the $\mathrm{CD} / \mathrm{DVD}$ player could be included. The second group of definitions includes the concept of e-learning in the narrower sense. Similar to using the prefix "e" in other words, such as e-commerce or e-business, the term e-learning stands for Internet-based applications. Only the Internet-based transmission of learning programs or content is implied here (Kerres, 2012). In her dissertation, Lenz (2009) points to a third possible definition of the term e-learning: learning just-in-time, i.e., independent of time and place. It is not of importance whether the process is on-line or off-line, nor which media is used. Despite the division of definitions into these three groups, the meaning of the term e-learning remains unclear and very broad. There is no clear distinction from computer-based training, educational television, webinars, online courses, videoconferencing, sharing of learning content via YouTube, social media, blogs, e-mail, Skype, chat, newsletters, etc. Can all of this be including under e-learning? The range of implementation of media-based learning offers seems to be very large. Where does learning end and pure communication or data exchange through various media-based channels begin? This question leads us to the next chapter, where we attempt to classify the forms of e-learning according to different criteria. Schnekenburger (2009) claims that there is no single concept of e-learning, as the ideas and technical developments are too different. New types of digital media and forms of information and data exchange are continually appearing and with them they bring new word combinations and terms around the topic of "e-learning". Therefore, the focus should no longer lie on the term e-learning, but on the forms and applications of e-learning for VET.

\subsection{Forms of e-learning}

As already mentioned in chapter 2.1, e-learning can be divided into two categories with regard to the type of electronic media used: online and offline, or web-based and computer-based. The first case involves learning on devices that have connection to the Internet. The second case refers to media that can be played back on devices without an Internet connection. We, however, go a few steps further and look at other forms of e-learning which are presented in the literature.

Hahne (2003) proposes a distinction between formal and informal e-learning. The criterion for this differentiation is logical and simple: formal or informal learning opportunities. Formal learning offers are courses or seminars that require formal registration. Such events are planned by a course provider, prepared for media transmission, and carried out at designated times. Usually a fee is required, and a virtual teacher/tutor/contact person is available to coordinate the learning process. Furthermore, formal e-learning is bound to certain learning objectives and qualifications, and ends with an exam, a certification or an authorisation. In informal e-learning, the learning process takes place in a more or less unplanned manner and via informal channels (YouTube, Facebook, Twitter, Xing, etc.). There is no teacher, and the learner is required to locate the information by himself or herself (Cox, 2013).

Meerten (2003) also differentiates between a functional and an intentional form of e-learning. Functional e-learning takes place on demand and usually during work hours. Here learning revolves around trying to find a solution to a specific problem or a clearly defined task. This refers to self-directed work or problem-related learning (Wang, 2018). The learner tries to find the required data and information independently (learning by doing). By contrast, intentional e-learning only takes place if the training is structured and prepared by a teacher in a didactic and methodological way. As such, an "intended" learning concept is one that is coordinated or controlled by a teacher.

De Witt (2012) proposes a different classification of e-learning. It is based on three learning trends: mobile learning, social learning, and game-based learning. Mobile learning takes place on mobile devices such as smartphones, notebooks or tablets with touchscreen. The mobile devices serve simultaneously as a source of information, a communication medium and a cognitive tool (Döring, 2005). Such forms of e-learning are becoming increasingly popular, as many learners own such devices privately and are often on the go. Social learning is a form of learning which reqires participation of interest groups or (learning) communities. Often, such virtual on-line communities can be found or created using social media (Facebook, Twitter, forums, 
LinkedIn, Xing, etc.). The exchange of information takes place within the communities of interest, which often quickly leads to successful learning thanks to the positive influence of group dynamics. The third form of e-learning according to De Witt (2012) is game-based learning. It is about learning through games (serious games, simulation games, computer games, etc.). In the process, a realistic environment is simulated in which the learner experiences different action situations according to defined rules of the game. Behind game-based learning, there are often not only stress-inducing elements or entertainment, but also mature didactic concepts that pursue specific learning objectives.

Zinke (2003) differentiates between teacher-centred, learner-centred and team-centred e-learning. The first case is a means of learning controlled by the teacher, the second, spontaneous and problem-oriented learning initiated by the learner, and the third, a learning approach in a group. A similar classification of e-learning is also presented in a paper by the German Federal Academy of Public Administration (BaköV, 2012). A distinction is made between four forms of e-learning: individual learning, tutorially supported learning, collaborative learning and blended learning. In individual learning, only the information available on the learning medium is available to the learner. In tutorial assisted learning, learners are supervised by a teacher. Collaborative e-learning involves learning in a virtual community. The tasks can be solved together and solutions can be discussed in the group. The final form is a mixed form of learning that combines electronically-based self-learning, face-to-face learning, and group work to achieve the best possible learning outcomes.

Goertz (2013) presents a two-dimentional view on learning forms based on digital media. The first dimension includes the criterion "learning offer" (formal or informal). The examples of formal learning forms could be webinars, virtual classrooms, serious games. etc. The informal learning forms include social networks, podcasts, webblogs, etc. The second dimension is based on the criterion "learning activity" (individual or collaborative). The individual learning focuses on such learning activities which the learner may perform alone (podcasts, videos, learning on demand, webblogs, etc.), whereas the collaborative form of learning requires the participation of more than one learner (social networks, chatting, virtual classroom, interctive whiteboard, etc.)

In summary, e-learning is characterised by a variety of forms. Some examples are webinars, virtual classrooms, serious games, podcasts, chats, forums, social media, business games, learning journals, educational films, etc. There are different criteria that could also be used as classification features. The main criteria can be systemized as follows: learning offer (formal, informal), learning objective (functional and intentional), learning trends (mobile learning, social learning and game-based learning), learning activity (individual, collaborative, tutorial), and learning medium (online and offline, or web-based and computer-based) (Figure 1).

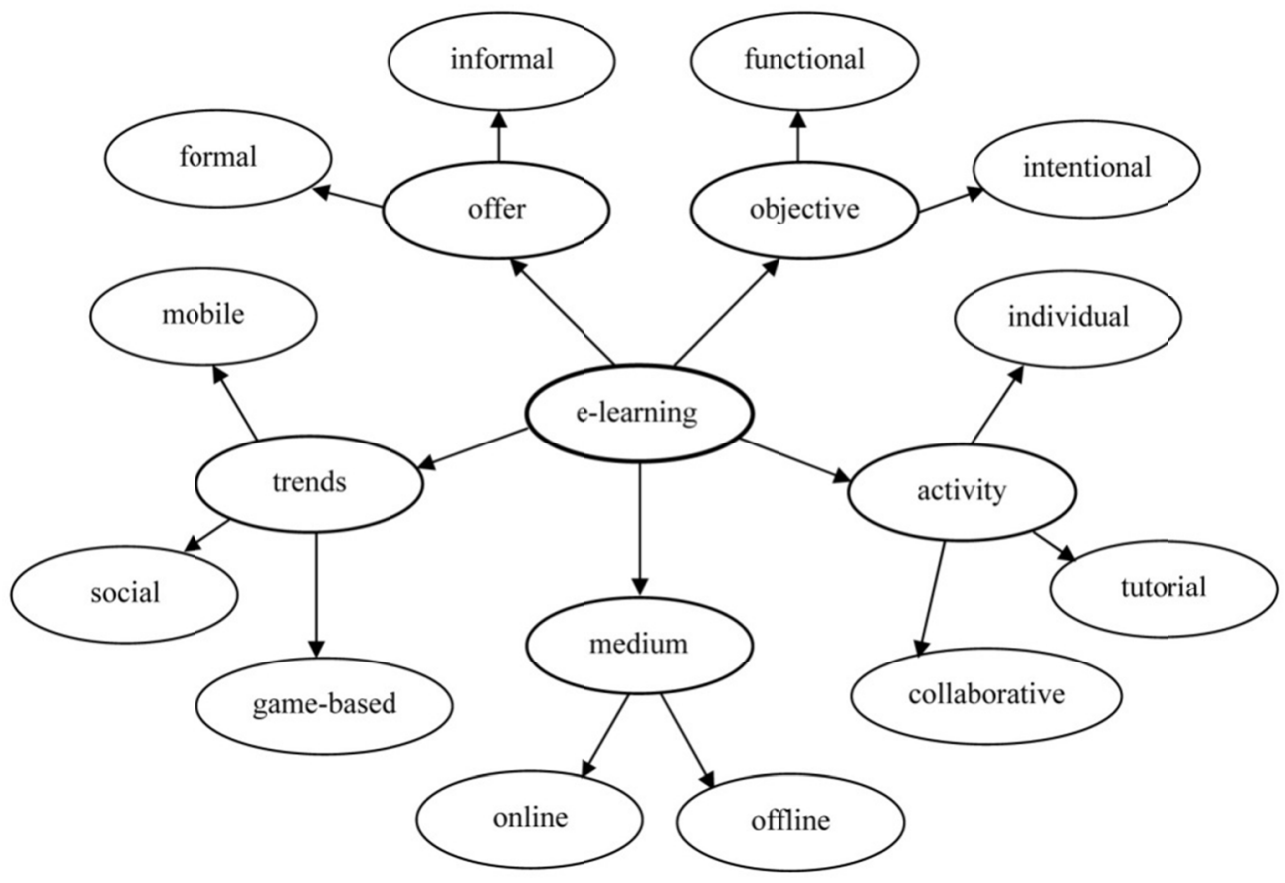

Figure 1. Classification of e-learning forms based on different criteria 


\section{Advantages and Disadvantages of e-learning Compared to Traditional Forms of Learning}

E-learning presents advantages as well as disadvantages for learners, teachers and providers (companies, training centres, VET schools). Initially, the use of new electronic media triggered great enthusiasm, but it was followed by disillusionment and scepticism (Njenga \& Fourie, 2010; MacKeogh \& Fox, 2009; Zimmer, 2005; Reglin \& Severing, 2003). It is, therefore, interesting to look at the positive aspects that led to such enthusiasm, as well as the negative features, risks and challenges that exist or could arise in the use of e-learning. A critical analysis of the advantages and disadvantages of e-learning compared to traditional learning formats could shed light on why the use of e-learning for VET has not always been as successful as initially hoped. We then attempt to derive some recommendations towards improving the application of e-learning.

\subsection{Advantages of e-learning}

E-learning has a number of advantages over traditional learning formats. Palmer (2002) argues that e-learning is the engine of modern education and training. Zinke (2003) claims that e-learning means that new learning content can quickly be made accessible to a large number of learners over long distances. In this way, providers save valuable time that learners would otherwise spend traveling. In addition, savings are made in terms of travel and accommodation costs as well as costs for the rental of training spaces. E-learning is particularly relevant for companies that have multiple locations in different regions or in hard-to-reach or remote areas. Kerres (2012) points to the possibility of individually adapting the learning content and the learning pace to the needs of the learners, which in his opinion can lead to a reduction of the learning time. E-learning enables students to develop their creativity and offers innovative learning scenarios and (media-based) didactic concepts, which results in the "transformation of the learning culture" (Reinmann-Rothemeier, 2003). Innovative learning concepts increase the motivation to learn and the success of the trainees. Overall, Kimiloglu et al. (2017) insist that the perceived advantages of e-learning prevail the disadvantages in an organizational context. Beinicke \& Bipp (2018) found out in their study that e-learning is at least as effective as classroom training and that the strengths of e-learning become more prevalent six to eight weeks after the training.

Since e-learning involves both learners and providers of e-learning courses, we would like to systemize the benefits of e-learning looking at the two groups of participants separately.

As a result of our literature review we found that e-learning offers the following benefits to learners. Learners are given great flexibility in the choice of location, timing, pace and content, as well as the ability to personalise learning objectives and content. The multimedia presentation of the learning content in the form of visualisations, animations, simulations, playful learning scenarios, and realistic and interactive exercises facilitate the learning process and increase learning motivation. Access to extensive learning content (links, search functions, glossaries, online libraries, etc.), and the use of communication and cooperation scenarios in virtual classrooms between learners and teachers as well as in groups of learners, are additional advantages. Learners are not afraid that they will have their knowledge gaps "exposed" in front of other participants. In addition, further monetary savings are made, as travel and accommodation costs are eliminated.

Advantages for course providers differ from those for learners. The providers are given the opportunity to produce, distribute and update learning content in a fast and temporally and locally independent manner. They also save on travel and staff costs. E-learning allows for an increased number of participants from different countries to take part and offers the possibility to connect interdisciplinary learning content.

Not only learners and course providers can benefit from e-learning. There are also other categories of participants, e.g. authors, lecturers, software developers and IT specialists who can receive more job orders and, thus, generate higher sales. However, we have deliberately omitted the benefits of e-learning for companies that send their employees to the training sessions. The reason for this is that the benefits for the learner also bring benefits to the employer. The companies benefit from the learning success of the learners and the cost savings. Also, the benefits to teachers/course leaders have not been highlighted in this paper because they are too specific or overlap with the benefits for course providers (e.g. challenges in designing and implementing learning opportunities or saving travel costs for the teacher).

\subsection{Disadvantages of e-learning}

The advantages of e-learning are offset by the disadvantages. Our literature research has shown that the following disadvantages can arise for learners. First and foremost, learners must have a high degree of self-discipline, time management skills, concentration and possibly pedagogical knowledge in order to independently control the learning process, as disturbances and distractions can occur more frequently than in the training room. In addition, learners must first build up media literacy and experience in using electronic 
media and programs in order to benefit from the multimedia presentation of learning content and the use of electronic learning resources. These additional requirements for learners can seriously affect the e-learning process and jeopardise the whole concept of e-learning. Some company surveys have already shown that small and medium-sized enterprise (SME) employees often do not have enough electronic media experience and have self-study difficulties (Anneken, 2016, Lenz, 2009). Since computers and the Internet are very frequently used in e-learning, there is a risk that the excessive use of electronic media can trigger addictive behaviour and mental illnesses (Braun, 2014). Currently, it is not clear at what point the use of a PC can be classified as "excessive". However, such dangers to the health of learners should not be underestimated. Another disadvantage is the use of virtual classrooms in e-learning. Learning in virtual classrooms differs from learning in groups at face-to-face events, as communication takes place without the mutual presence of the participants. For this reason, learners can only develop their social skills to a limited extent and are unable to benefit sufficiently from group dynamics (Kohl, 2004). Students have to come to terms with a series of restrictions on signals of attention and confirmation that promote understanding of the subject matter in the classroom (Wache, 2003). Many participants of online courses suffer from isolation and anonymisation. They lack social interaction with other learners or teachers, which can significantly impair their motivation to learn (Sitzmann, 2015). They need to learn how to properly communicate in virtual groups and understand other group members. Otherwise, misunderstandings can occur that adversely affect the learning success. The savings in travel and accommodation costs are countered by additional costs for setting up workplaces or offices so that they are suitable for e-learning. These include the cost of fast data transmission via high-speed Internet and possible acquisition costs for computers, laptops, tablets or other learning media.

The providers of e-learning courses are also faced with a number of problems and challenges. These include technical, didactic and organisational challenges in the design and implementation of learning opportunities. There are many additional tasks for e-learning course providers (Ghetto, 2013). Because the learning materials need to be designed in such a way as to make them effective and user-friendly (Fleming et al., 2017), the learning platforms have to be set up and supervision/support/maintenance must be organised.

Providers must first invest in the quality of the products so that the learning content has interactive elements and provides opportunities to communicate with other learners. This means additional costs for digital learning materials, software solutions, design, and implementation. Many learners also fear that they will be faced with textbook-like learning content, which will bore them and make little sense (Huchthausen \& Droste, 2014). In addition, not all topics lend themselves to mediation by electronic media, e.g. soft-skills (Lenz, 2009). These include topics such as conflict resolution, team skills, rhetoric, and presentation techniques. There are also additional problems attached to conducting online courses. The teachers or course instructors must control the communication process with the learner by means of specific instruments or defined text signals and coordinate the flow of dialogue. In addition, they will need to set new criteria for assessing virtual credentials that are appropriate for virtual classrooms. Besides, some teachers oppose to the use of new technologies in the classroom and do not recognize the positive aspects of e-learning (Callan et al. 2015; Njenga \& Fourie, 2010). Another barrier to the use of e-learning in VET is resilience of some institutions toward innovations (Schmidt, 2015).

The advantages and disadvantages of e-learning for learners and providers, which we have already identified, are presented in Table 1.

Table 1. Advantages and disadvantages of e-learning for learners and providers

\begin{tabular}{ll}
\hline Advantages & Disadvantages \\
\hline For learners & \\
\hline Flexibility of choice of place, time, learning pace, and content & $\begin{array}{l}\text { Learners must have a high degree of self-discipline, time } \\
\text { management, concentration, and possibly pedagogical knowledge to }\end{array}$ \\
$\begin{array}{l}\text { Shortening of the learning time through the possibility of } \\
\text { individualizing the learning objectives and content and the } \\
\text { learner's control of the learning process }\end{array}$ & $\begin{array}{l}\text { independently control the learning process, as disturbances and } \\
\text { distractions can occur more often than in the seminar room }\end{array}$ \\
\hline $\begin{array}{l}\text { Increase of motivation to learn thanks to the multimedia } \\
\text { presentation of learning content in the form of visualizations, } \\
\text { animations, simulations, playful learning scenarios, and realistic } \\
\text { and interactive exercises }\end{array}$ & $\begin{array}{l}\text { There is a risk that the excessive use of the computer and the } \\
\text { internet can take addictive traits and can lead to mental illness }\end{array}$ \\
\hline $\begin{array}{l}\text { Facilitating the learning process by accessing extensive learning } \\
\text { content (links, search functions, glossaries, online libraries, etc.) }\end{array}$ & $\begin{array}{l}\text { In order to benefit from the multimedia presentation of learning } \\
\text { content and the use of electronic learning resources, learners must } \\
\text { first build up media literacy and gain experience in using electronic } \\
\text { media and programs }\end{array}$ \\
\hline
\end{tabular}




\begin{tabular}{|c|c|}
\hline $\begin{array}{l}\text { Interest and fun in learning through the use of communication and } \\
\text { cooperation scenarios in virtual classrooms between learners and } \\
\text { teachers as well as in groups of learners }\end{array}$ & \multirow{2}{*}{$\begin{array}{l}\text { Learning in virtual classrooms differs from learning in groups at } \\
\text { face-to-face events because communication is not personal. The } \\
\text { learners can not develop their social skills and can not benefit } \\
\text { sufficiently from the group dynamics }\end{array}$} \\
\hline $\begin{array}{l}\text { Learners are not "exposed" to their knowledge gaps in front of } \\
\text { other participants }\end{array}$ & \\
\hline Savings on travel and accommodation costs & $\begin{array}{l}\text { Workplaces or private homes must be suitable for e-learning, i.e. } \\
\text { additional costs for high-speed internet and computers, laptops, } \\
\text { tablets or other mobile devices }\end{array}$ \\
\hline \multicolumn{2}{|l|}{ For providers } \\
\hline $\begin{array}{l}\text { Temporally and locally unlimited and fast production, distribution } \\
\text { and updating of the learning content }\end{array}$ & $\begin{array}{l}\text { Technical, didactic, and organizational challenges in the design and } \\
\text { implementation of learning opportunities }\end{array}$ \\
\hline $\begin{array}{l}\text { Savings on travel costs, rental costs for seminar rooms, and staff } \\
\text { costs }\end{array}$ & $\begin{array}{l}\text { It is necessary to invest in quality of the products so that the } \\
\text { learning content has interactive elements and possibility to } \\
\text { communicate with other learners (costs of digital learning materials, } \\
\text { software solutions, design, and implementation personnel costs) }\end{array}$ \\
\hline $\begin{array}{l}\text { Increase in the number of participants from different countries } \\
\text { (internationalization) }\end{array}$ & $\begin{array}{l}\text { Not all topics are suitable for teaching via electronic media, e.g. soft } \\
\text { skills }\end{array}$ \\
\hline Possibility of connecting of interdisciplinary learning contents & Challenges in defining the criteria for assessing virtual proficiency \\
\hline
\end{tabular}

Source: author's systematization.

An attempt was made to contrast and compare them thematically. The comparison and critical analysis of the pros and cons attributed to e-learning in the literature allows us to draw some conclusions about the possible problems and potentials of e-learning in VET.

\section{Summary and Conclusions}

The literature analysis showed that most definitions of e-learning can be divided into three categories. The first category of definitions comprises e-learning as a generic term for learning by using electronic media in the broad sense. All kinds of media are included: computer, Internet, TV, radio, telephone, mobile phone, CD-ROM, CD/DVD player, etc. The second category of definitions covers the concept of e-learning in the narrower sense. Similar to using the prefix "e" in other words such as e-commerce or e-business, the term "e-learning" stands for learning using Internet-based applications. The third category of definitions interprets e-learning as "just-in-time" learning (independent of time and place). It does not pay close attention to which media are used and whether an Internet connection is needed.

E-learning is characterised by a variety of forms. Some examples include webinars, virtual classrooms, serious games, podcasts, emails, chats, forums, social media, business games, learning journals, educational films, etc. There are several criteria that could be used as classification features: learning offer (formal, informal); learning activity (individual learning, collaborative learning); learning medium (online and offline, or web-based and computer-based); learning objective (functional and intentional); and learning trends (mobile learning, social learning and game-based learning).

E-learning has a number of advantages and disadvantages compared to traditional classroom teaching. We looked at the pros and cons from two perspectives: the learner's perspective (apprentice, staff, students, trainees) and the provider's point of view (VET institution, training centre, companies, etc.). The presentation of the pros and cons from the perspective of the teacher or lecturer, was deliberately omitted because it overlaps. The literature review found that learners value the following aspects of e-learning: flexibility in choosing location, timing and pace of learning; reduction of the learning time by individualisation of the learning content; increased motivation to learn thanks to multimedia presentations, access to online libraries and the use of virtual classrooms; and elimination of travel and accommodation costs. However, learners also need to consider some risks: e-learning requires self-discipline and media literacy, can trigger an addiction through excessive use of electronic media, slows the development of social skills through spatial isolation of participants, and requires the workplace to be technically equipped.

Providers of e-learning courses also benefit from the flexibility in terms of time and space, which reduces costs. There is, furthermore, the possibility of connecting interdisciplinary learning content and promoting the internationalisation of teaching. However, to take advantage of these benefits, providers must overcome some challenges. Virtual learning offers must be well planned and implemented technically, didactically and organisationally, which requires additional effort. In addition, some sensitive topics are not suitable for teaching by electronic media. Controlling the learning process is also problematic because of the physical distance of the students. The table of the advantages and disadvantages of e-learning can be used as a checklist in the planning 
or conception phase of an e-learning course. In this way, failures and frustrations on the part of providers and learners can be avoided in the future.

The topic of "e-learning" in the context of VET is still highly topical and represents a very promising and forward-looking opportunity for education and training (Howe \& Knutzen, 2013). Huchthausen \& Droste (2014) especially recommend e-learning to such providers that have multiple locations, need to repeat training frequently, and often need to conduct new product training designed for a large number of learners. For such providers, the use of e-learning to educate learners is indispensable and results in very high cost savings and more effective resource allocation.

The use of new media in VET offers great opportunities in terms of improving the quality of education and reducing costs, but presents major challenges to all stakeholders. Unfortunately, e-learning is currently used by only a small number of companies (Anneken, 2009). Some companies have either turned away from e-learning due to their negative experiences or deliberately decided against it because of the existing risks. In such companies, the potential offered by this form of learning cannot be fully exploited. However, further education is a key success factor for the economy. Therefore, providers of e-learning courses should create the necessary framework conditions and incentives for learners who favour the use of "e-learning". In order to minimise the risks involved in using e-learning, the concept of blended learning (mixture of online and face-to-face events) could be used (Sitzmann, 2015). The combination of two forms of learning can reduce the disadvantages and allow the best possible use of the potentials and opportunities of both forms. Another recommendation addresses the quality of e-learning opportunities. In order to counteract the possible risks and disadvantages of e-learning, pedagogical concepts should be designed and developed explicitly for e-learning. Lesson design and media use need to be rethought and adapted as needed. The media skills of learners and teachers should also be verified before the e-learning process begins and revised, if necessary.

It is clear that our everyday lives are dominated by new media. They fascinate us and irritate us at the same time. However, there is no way around these media and, therefore, e-learning will continue to play an important role in the future. However, only when the social, organisational and individual requirements are met, can e-learning truly develop its potential.

\section{References}

Anneken, S. (2016). Chancen und Grenzen des Mobile Learning aus Sicht von kaufmännischen Mitarbeiter(inne)n, Medienproduktion - Online Zeitschrift für Wissenschaft und Praxis, Ausgabe 10, S. 30-35.

http://www5.tu-ilmenau.de/zeitschrift-medienproduktion/index.php/chancen-und-grenzen-des-mobile-learni ng-aus-sicht-von-kaufmaennischen-mitarbeiterinnen/

BaköV (2012). Chancen und Grenzen von E-Learning und Blended Learning in der dienstlichen Fortbildung, Bundesakademie für öffentliche Verwaltung (BaköV). Retrieved from http://www.bakoev.bund.de/SharedDocs/Downloads/LG_5/elearning_Konzept_BAkoeV_NEU.pdf?_blob $=$ publicationFile

Balanskat, A., Blamire, R., \& Kefala, S. (2006). The ICT impact report: A review of studies of ICT impact on schools in Europe, European Commission, Brussels. Retrieved from http://unpan1.un.org/intradoc/groups/public/documents/unpan/unpan037334.pdf

Beinicke, A., \& Bipp, T. (2018).Evaluating Training Outcomes in Corporate E-Learning and Classroom Training.Vocations and Learning, pp. 1-28. https://doi.org/10.1007/s12186-018-9201-7

Braun, U. (2014). Exzessive Computer-und Internetnutzung Jugendlicher - Überblick über den aktuellen Forschungsstand. Exzessive Internetnutzung Jugendlicher im familialen Kontext,pp. 15-22. Wiesbaden: Springer. https://doi.org/10.1007/978-3-658-04197-7_2

Brolpito, A., Lightfoot, M., Radisic, J., \&Scepanovis, D. (2016). Digital and online learning in vocational education and training in Serbia, European Training Foundation. Retrieved from https://www.etf.europa.eu/webatt.nsf/0/DC024C02AA9B9384C12580280043A0B6/\$file/DOL\%20in\%20V ET\%20in\%20Serbia.pdf

Callan, V.J., Johnston, M.A., \& Poulsen, A.L. (2015). How organisations are using blended e-learning to deliver more flexible approaches to trade training. Journal of Vocational Education \& Training,67(3), 294-309. https://doi.org/10.1080/13636820.2015.1050445 
Cox, M.J. (2013). Formal to informal learning with IT: research challenges and issues for e-learning. Journal of Computer Assisted Learning, Special Issue: Knowledge Transformation, Design and Technology, 29(1), 85-105. https://doi.org/10.1111/j.1365-2729.2012.00483.x

De Witt, C. (2012). NeueLernformenfür die beruflicheBildung: Mobile Learning - Social Learning - Game Based Learning, BWP 3/2012, S. 6-9. Retrieved from https://www.bibb.de/veroeffentlichungen/en/publication/download/6881

Dittler, U. (2003). E-Learning: Einsatzkonzepte und Erfolgsfaktoren des Lernens mit interaktiven Medien, 2.Auflage, München.

Döring, N. (2005). Mobile Kommunikation. In J.Hüther\& B.Schorb (Hrsg.), Grundbegriffe Medienpädagogik(pp. 318-326). München, S.

Eickhoff, A. (2008). E-Learning in der Sportausbildung und-weiterbildung. Deutsche Sporthochschule Köln, Dissertation.

Fleming, J., Becker, K., \& Newton, C. (2017). Factors for successful e-learning: does age matter? Education + Training,59(1), 76-89. https://doi.org/10.1108/ET-07-2015-0057

Getto, B. (2013). Anreize für E-Learning. Eine Untersuchung zur nachhaltigen Verankerung von Lerninnovationen an Hochschulen.Universität Duisburg-Essen, Dissertation.

Goertz, L. (2013). Indikatorengestützte Zeitreihe über die Nutzung digitaler Medien in der beruflichen Aus- und Weiterbildung, Institut für Medien- und Kompetenzforschung (MMB).Retrieved from http://datenreport.bibb.de/media2013/expertise_goertz.pdf

Gros, B., \& García-Peñalvo, F.J. (2016).Future Trends in the Design Strategies and Technological Affordances of E-Learning.In M.Spector, B.Lockee, \&M. Childress (Eds.),Learning, Design, and Technology.Springer, Cham. https://doi.org/10.1007/978-3-319-17727-4_67-1

Hahne, K. (2003). Für ein anwendungsbezogenes Verständnis von E-Learning, BWP 4/2003, S. 35-39. Retrieved from https://www.bibb.de/veroeffentlichungen/en/publication/download/810

Heuel, E., \& Feldmann, B. (2014). Quality Standards for e-Learning in Vocational Education and Training: The Certified European E-Tutor. InL.Uden, Y. H.Tao, H. C.Yang, \&I. H.Ting (Eds.),The 2nd International Workshop on Learning Technology for Education in Cloud. Springer Proceedings in Complexity. Springer, Dordrecht. https://doi.org/10.1007/978-94-007-7308-0_10

Howe, F., \& Knutzen, S. (2012). Digitale Medien in der gewerblich-technischen Berufsausbildung, Studie im Auftrag des Bundesinstituts für Berufsbildung, Bonn. Retrieved from https://www.bibb.de/dokumente/pdf/Expertise_Howe_Knutzen.pdf

Huchthausen, M., \& Droste, M. (2014). E-Learning: Vor- und Nachteile des onlinegestützten Lernens, ddm, Ausgabe $\quad 4, \quad$ S. $\quad 82-83.6$ Retrieved http://digital-dental-magazin.de/wp-content/uploads/13_E-Learning-Vor-und-Nachteile-des-onlinegest\%C3 $\%$ BCtzten-Lernens.pdf

Kerres, M. (2012). Mediendidaktik. Konzeption und Entwicklung mediengestützter Lernangebote, 3. Vollständig überarbeitete Auflage. München: Oldenbourg Verlag.

Kimiloglu, H., Ozturan, M., \& Kutlu, B. (2017). Perceptions about and attitude toward the usage of e-learning in corporate training.Computers in Human Behavior, 72, 339-349. https://doi.org/10.1016/j.chb.2017.02.062

Kohl, E. (2004). Entwicklung einer Strategie für die didaktische Begleitung von E-Learning-Vorhaben zur Virtualisierung der Hochschullehre am Beispiel des Forschungsprojekts ITO.Pädagogischen Hochschule Ludwigsburg, Dissertation.

Lehmann, B., \& Bloh, E. (2002). Online-Pädagogik, Schneider Hohengehren.

Lenz, K. (2009). Akzeptanz von E-Learning in KMU.Universität Erfurt, Dissertation.

MacKeogh, K., \& Fox, S. (2009). Strategies for Embedding e-Learning in Traditional Universities: Drivers and Barriers.Electronic Journal of e-Learning, 7(2), 147-154. Retrieved from http://www.ejel.org/issue/download.html?idArticle=149

Meerten, E. (2003). Auftragsbezogene Leittexte und Lernkonzepte im Handwerk. In BIBB (Hrsg.),Berufliche Bildung, S. 574-576.

Njenga, J.K., \& Fourie, L.C.H. (2010).The myths about e-learning in higher education.British Journal of 
Educational Technology, 41(2), 199-212. https://doi.org/10.1111/j.1467-8535.2008.00910.x

Palmer, C.-E. (2002). eLearning? die Revolution des Lernens gewinnbringend einsetzen. In U. Scheffer\&F. W.Hesse (Hrsg.), eLearning. Die Revolution des Lernens gewinnbringend einsetzen, S. 13-15.

Reglin, Th., \& Severing, E. (2003). Konzepte und Bedingungen des Einsatzes von eLearning in der betrieblichen Bildung - Erste Ergebnisse der Begleitforschung des Projekts"bbw online". In E. U. A.: eLearning für die betriebliche Praxis, Bielefeld 2003, S. 9-23. Retrieved from https://www.bibb.de/dokumente/pdf/einsatzbedingungen-e-learning.pdf

Reinmann-Rothmeier, G. (2003). Didaktische Innovationen durch Blended Learning: Leitlinien anhand eines Beispiels aus der Hochschule. Bern: Huber.

Riekhof, H.-Ch., \& Schüle, H. (2002). E-Learning und Wissensmanagement in deutschen Großunternehmen. Retrieved from www.forschungsnetzwerk.at/downloadpub/elearningstudie.pdf

Schmidt, C. (2015). Innovation and structural change in German vocational education and training.International Journal of Innovation in Education, 3(1), 34-44.

Schnekenburger, C. (2009). E-Learning an der Universität Rostock. Eine explorative, quantitative Online-Trenderhebung zum tatsächlichen Einsatz von Stud.IP. Dissertation.

Sitzmann, D. (2015). Rahmenwerk für zielgruppenorientiertes Blended E-Learning im MINT-Bereich im Kontext des Lebenslangen Lernens. Technische Universität Clausthal, Dissertation.

Strittmatter, P., \& Niegemann, H. (2000). Lehren und Lernen mit Medien. Wissenschaftliche Buchgesellschaft, Darmstadt.

Wache, M. (2003). E-Learning - Bildung im digitalen Zeitalter, Bundeszentrale für politische Bildung, 2003. Retrieved from http://www.ihi-zittau.de/de/dnl/bildung_im_digitalen_zeitalter.1360.pdf

Wang M. (2018). A Framework of Performance-Oriented Workplace e-Learning.In E-Learning in the Workplace.Explorations in the Learning Sciences, Instructional Systems and Performance Technologies.Springer, Cham. https://doi.org/10.1007/978-3-319-64532-2_9

Zimmer, G. (2005). Gestaltung einer Strategie zum Aufbau virtueller Studienangebote. InD.Euler\&S.Seufert (Eds.), E-Learning in Hochschulen und Bildungszentren. E-Learning in Wissenschaft und Praxis, Band I (pp. 1-24). München: Oldenbourg Verlag.

Zinke, G. (2001). E-Learning am Arbeitsplatz - Eine Herausforderung an die Bildungstechnologieforschung, BWP 5/2001, S. 41-45. https://www.bibb.de/veroeffentlichungen/de/publication/download/628

\section{Copyrights}

Copyright for this article is retained by the author, with first publication rights granted to the journal.

This is an open-access article distributed under the terms and conditions of the Creative Commons Attributionlicense (http://creativecommons.org/licenses/by/4.0/). 